\title{
The Autobiography of Grace, Lady Mildmay
}

RANDALL MARTIN

Summary: The following is an annotated transcription of Lady Grace Mildmay's autobiographical papers, written between 1617 and 1620. These "Memoirs" reveal the preoccupations and moral teachings of an Englishwoman brought up in the reformed faith. They also contain a wealth of information on monetary transactions and fiscal practices involving Lady Mildmay and her husband Sir Anthony.

L

ady Grace Mildmay's autobiographical papers are among the most personally revealing writings we possess by a Renaissance Englishwoman. Until recently, however, the only available printed version has been brief excerpts in an article published by Rachel Weigall in 1911. ${ }^{\prime}$ We have Weigall to thank for introducing us to Lady Mildmay with an engaging outline of her life, but regrettably the excerpts themselves have been silently altered and emended. And although an anthology of Renaissance women writers published in 1981 also contains short passages by Lady Mildmay, because these are taken from Weigall, they too are unreliable. ${ }^{2}$ Nonetheless the original MS is extant and consists of two distinct parts now bound in a dark-blue half-leather volume. ${ }^{3}$ The large second part, which Lady Mildmay began in her youth and continued writing intermittently throughout her life, she calls her "Book of Meditations." It opens with what is evidently a late addition, a twelve-page dedication to her daughter Mary, to whom she wills her bible, her copies of Musculus's Commonplaces and Commentaries, Foxe's Book of Martyrs, Thomas à Kempis's Imitation of Christ, and the meditations that follow, "which ... hath bene to mee, as Iacobs ladder, \& as Iacobs pillar, euen a booke of testimonyes 
betweene God and my soule". ${ }^{5}$ The latter begin on page 13 and are a loose compendium of: "Principall poyntes to be obserued in reading the Holy S[c]riptures", brief summaries of saints' lives and virtues based on accounts in Foxe, prayers and biblical excerpts for various occasions, moral precepts and sententiae (some passed on by Lady Mildmay's mother and grandmother), accounts of spiritual mercies, and transcriptions and/or paraphrases of scriptural passages. The last of these in fact make up the bulk of this part of the MS. Typically Lady Mildmay will open with a biblical text, perhaps one she has heard recently in church, and then meditate upon it by cross-referencing scriptural passages which she sometimes comments upon; her approach is typological and copious. Yet despite its considerable length, this "Book of Meditations" supplies virtually no information about the writer's life, times, or opinions besides that which is moral or theological ${ }^{6}$ During most of the years she was writing these pages, it seems Mildmay did not think of herself as an "author." She neither refers to topical events nor adopts presentational strategies which might be used to carry along an imagined audience. There is an absence, in other words, of the kind of reader-postulated detail that one sees in other manuscripts by Renaissance women such as Elizabeth Delaval's "Memoirs and Meditations." In character, therefore, this part of the volume represents a private devotional exercise, as Lady Mildmay considers her ability to interrelate points of scripture a mark of divine grace. ${ }^{8}$

Despite this prevailing conception of her meditations as a personal aid to spiritual growth, at some stage she began to conceive of them as counsel to be passed on to her daughter and grandchildren; and after the death of her husband in 1617 , and before her own death in 1620 , she decided to gather them together and preface them with an autobiographical account, "as familiar talke \& communicacion with [my family], I being dead, as yf I were aliue." By this point she also held open the possibility of her meditations being seen by general readers, who she hoped might "make good use of them." Thus, in a strategy distantly reminiscent of saint Augustine introducing The City of God with his Confessions, and subsequently common to many protestant writers, Mildmay's presentation piece acts as a profession of personal faith and integrity prior to the main "prophetical" exercise. This first part of the MS ( 85 pages) recalls significant events and people in the author's life - social, intellectual, and spiritual - interspersed with moral advice supported by scriptural proofs. It begins with a comparatively full list of recommended books and areas of secular and religious knowledge, reaching considerably beyond the common 
minimum (at least for women) of the bible alone. Some of this section may have been lost, as "Cap: 8" in Lady Mildmay's hand appears on the first page at the top of the margin. ${ }^{9}$ At the end of the main autobiography marked "Finis" on p. 61, a subsection follows entitled "The Authors Meditation vpon her Corps." This was written immediately after the death of her husband and before his burial. It is this first part of the MS relating key episodes in Lady Mildmay's life that is of most interest to modern readers.

Grace was the second daughter of Sir Henry Sharrington and Ann Paggett of Lacock Abbey, Wiltshire. After the death of her elder sister Ursula she became co-heir of her father's estates, but had great difficulty securing her inheritance because of a dispute with her younger sister Olivia. The "conspiracye" in which this sister and other members of her family persuaded the dying Sir Henry into altering his will to reduce Grace's share of the estate, as well as their later efforts to defraud her of her mother's bequest, are dramatically portrayed in this section of the volume. Here as at other points one receives a strong impression of Lady Mildmay wishing to make known her side of the story to engage her readers' sympathies, and deliberately shaping it to reveal God's presence in the just resolution of her difficulties. She seeks to defend her innocency, and at the same time ventilate emotions long suppressed but still potentially disturbing to her own standards of moral conduct.

Prior to the dispute over her inheritance she had married Anthony Mildmay in 1567 at the age of 15 . He was the eldest son and heir of Sir Walter Mildmay, Chancellor of the Exchequer from 1566 until his death in 1598, and founder of Emmanuel College Cambridge. Grace seems to have become a favourite of his, for reasons going beyond the simple wish of seeing dynastic arrangements with the Sharringtons concluded amicably. She tells how Sir Walter not only overcame Anthony's tepid enthusiasm towards marrying her with a combination of threats and pecuniary inducements, but also how he intervened successfully on her behalf in the legal dispute with her sister. She also echoes contemporary praise of him as one of Elizabeth's most capable and upright ministers, ${ }^{10}$ while commending his personal godliness and benevolence at home, qualities she had ample opportunity to observe since she and Anthony lived for nearly twenty years at Apethorpe, Sir Walter's seat in Northamptonshire.

On the other hand while recalling him with respect and genuine affection, Lady Mildmay does not hide her disappointment with her father-in-law's failure to make over the jointure he had promised upon marriage. It is also clear that Grace believes she and her husband were stinted of the full support Sir 
Walter had pledged them. Like other country gentlewomen of her time, ${ }^{11}$ the burden of managing and running the household fell mainly on her, but in this case on the inadequate annual allowance of "but $130^{\text {fi }}$ by yeare bare pention." This led to "many afflictions \& contrary occasions $\mathrm{w}^{\mathrm{ch}}$ fell out betwixt me \& my husband \& betwixt vs \& [her parents-in-law]." Since she possessed no substantial property of her own, she experienced further anxiety in the event that her husband should die before inheriting, which at several points seemed likely when he was either ill or in danger. During this time Anthony was regularly in attendance at court (a further source of worry when he "had a splinter of a launce rann farre into the middest of his forehead" while running at tilt), and between 1596-1597 he served as ambassador to France, having been knighted prior to the posting. These and other activities, such as aiding Sir Edward Montague in putting down rebels at Newton Field, and maintaining men and horses against the Spanish in the Netherlands, ${ }^{12}$ caused him to go deeply into debt, thereby heightening his wife's sense of vulnerability. Sir Anthony planned to pay off his debts upon inheriting, since he hoped to see his father's original vow fulfilled of giving him "all that I haue, \& whatsoeuer els I can procure." Yet after Sir Walter's death the Mildmays were again disappointed of their expectations. Grace still received no jointure, while her husband inherited only a little over half the total estate. ${ }^{13}$ She claims that her brother-in-law Humphrey was bequeathed the remainder, but in fact he received less than one quarter, the rest going to charity and other relations. ${ }^{14}$ That she and her husband were still short of money is attested by her account of making over "all my present possession of myne owne inheritance being the flower \& best parte of my whole portion" to provide her daughter Mary with a dowry. The family's continuing financial problems led Sir Antony first to seek Parliamentary redress to claim a portion of the lands entailed to his brother, and then, when his brother contested this, to sue him, this time successfully. It was only after this that the Mildmays were well off, and (to judge from Grace's comments made after her husband's death) that what had often been a strained marriage became genuinely companionable. Her story not only confirms the conventional impression of a litigious age, but also speaks movingly of the distress faced by women who, after marriage, risked isolation and penury in the absence of strictly negotiated settlements, or indeed of any independent legal rights.

Of her childhood Grace recalls a rigorous but happy up-bringing by her governess, Mrs Hamblyn, ${ }^{15}$ whose values and advice, reinforced by the example of Lady Sharrington's deep piety, she commends to her children. The 
importance of a simple reformed faith, and accountable behaviour, were impressed upon her from an early age, and these habits seem to have become stronger over the years, partly under the influence of her father-in-law. Her own father seems not to have been quite so strict, since all the family visitors and guests she recalls from childhood are characterised by moral faults or "impudent behauiour" (e.g. a common-law couple). In this particular section of the autobiography, as Mary Ellen Lamb has observed, we also receive one of the most detailed "representations of the actual teaching offered to a young woman of the Renaissance." 16 Grace learned skills conventional to her sex, class, and religion: music, arithmetic, letterwriting, needle-work, basic surgery and physic, and daily scripture reading - a curriculum intended to produce pious and useful domestic companions for men. While being taught to avoid such works of the devil as "bookes of idle playes," she was also encouraged to write poetry on moral themes. In the case of the "impudent" couple mentioned above, both she and her governess composed stanzas "very wittily \& sharpe against such licentious behauiour ... to take heed of the lyke, \& to abhorre \& despise the same." Later as a young wife during her husband's long absences from home, Lady Mildmay proudly resisted invitations from friends to attend weddings and feasts, claiming that she was happier pursuing improving tasks at home than leading a more out-going, glamorous life. That she forcefully articulates the moral beliefs underpinning these decisions and deftly justifies them with scriptural evidence, while at the same time disabling her personal authority by drawing attention to her lack of scholarly training, makes her typical of many Renaissance women torn between confidence in the value of their convictions and fear of intruding on male-dominated areas of knowledge. By invoking the supervailing presence of divine grace in her "Bock of Meditations," however, Lady Mildmay, like other female authors of her time, overcomes traditional objections to women as moral teachers. Overall, then, this autobiographical part of the MS authenticates her lateconceived desire to circulate her meditations as a spiritual resource for public readers as well as her family. It likewise guarantees the autonomous transmission of a personal heritage, which previously in the legal and financial realms she had seen secured only with a much more painful and assisted struggle.

\section{The MS and transcription}

I have selected those passages from the autobiography which should be of any historical or literary interest to general readers; in all this represents about 
65 per cent of the first part of the MS. The omitted sections are those in which Lady Mildmay amplifies or cites biblical authority for moral advice that intersperses her temporal recollections. My transcription preserves original spellings, pagination, and paragraphing, but does not reproduce the bold lettering that occasionally begins a paragraph, the long form of $s$, blotted letters, or overwritten corrections/false starts. Also omitted are the numerous marginal references to biblical texts (some of which appear to be in hands other than Lady Mildmay's), as well as braces and other non-lexical markings. Contractions indicated by tildes have been expanded, and the swash terminal $s(S)$ is rendered es. All interpolated material appears in square brackets. The notes are editorial.

Two distinct hands appear in this first part of the volume. Lady Mildmay wrote the main text in a neat italic script. After this revisions and corrections, usually interlined by way of carets or strike-outs, were made in secretary script. This turns out to be her hand as well - an informal one -- since she sometimes also makes changes in italic which follow initial secretary revisions. On p. 3 of the MS, for example, paragraph 3, the penultimate line, she first writes "vsed" (italic), strikes this out and replaces it with "exercised" (italic, above the line), then strikes out this and returns to "vsed" (secretary, below the line), before again striking this out and writing "vsed" (italic, above the line). Moreover, isolated secretary letters often "creep in" to her formal hand letters identical in form to those of the script making revisions; e.g. p. 4 of the MS, paragraph 1, final line, the ' $r$ ' of 'introduction.' Since both hands are Lady Mildmay's, I have not distinguished between them in print, though the reader can assume that MS revisions generally appear in secretary.

Other than the marginal notes, the only other section of the first part of the MS not in Lady Mildmay's writing is an elementary family tree which appears on the verso of the cover-leaf (not reproduced here - recto blank). This begins with Sir Thomas Mildmay (father of Sir Walter) and ends with Grace's grandchild Mildmay Fane, son of her daughter Mary and Francis Fane, first Earl of Northumberland. The tree may have been added by Lady Fane. ${ }^{17}$ 


\section{Lady Grace Mildmay}

Autobiography (c.1617), from Meditations (?-1617?)

\section{[p.] 1}

experience I comend vnto my children as approoued,

I haue found by obseruation

this to be the best course to set our selues in from

the beginning vnto the end of our lyues./

That is to say

First To beginn $w^{\text {th }}$ the Sriptures [sic] to read them

$\&$ humility as a disciple

with all diligence ${ }_{\wedge}$ continually euery daye in some

measure vntill we haue gone thorough the whole booke of God from the first of Genesis vnto the last of the reuelation, $\&$ then beginn agayne $\&$ so ouer $\&$ ouer $w^{\text {th }}$ out wearynesse:/

To the end that; our, hart, soule, spirits, and with it

whole inner man, maye first be seasoned ${ }_{\wedge} \&$ receiue the true stampe \& lyuely impression thereof./

$$
\text { Judge }
$$

Whereby we maye the better ${ }_{\wedge}$ of all Learning Whatsoeuer, $\&$ be able to make true vse, and application application good $_{\wedge}$ distribution of all mens judgements and

$\&$ be conferred in educations: with this constant resolution, neuer to receiue any doctrine from men $w^{\text {ch }}$ procedeth not from God, according to the truth of his

$$
\text { ie }
$$

Worde in all sanctitude \& true holynesse./ As The holy sacraments baptisme \& the Lords Supper maye confirme $y$ same within vs $\&$ seale it vp for euer, betwixt God \& our consciences neuer to be altred that we are the selected people of God, to doe his will, to blesse his holy name, \& to publish his separatect \& opposed prayse, truely ${ }_{\wedge}$ tistinguished from sathan $y^{e}$ flesh, 
separated \& opposed

$\& y^{e}$ worlde,

\section{[p.] 2}

$\&$ the world \& from all theyr wicked actions \& conspiracies.l

Also to make our selues expert in the knowledge of the histories contayned in the booke of Acts $\&$ Monuments ${ }^{18}$ of the church, Whereby our faithfull zeale

^ may be increased \& strengthened \& our hartes encouraged manfully to suffer death $\&$ to giue truth

our lyues for the testimony of the teath of in

God Wheretnto we are thus confirmed and sealed by the death \& bloud of Christ.

Also to make our selues expert in the vnderstan= ding \& knowledge of the cronicles of the tad, land, What matters of moment haue passed from the beginning, vnder the gouernment of our Royall \& Annoynted Princes, Whereby

to imitiate \& we may be instructed to follow the good exam= ples of true \& faithfull subiects, and to haue theyr worthy actes \& exploytes in memory which are registred for the same end, and also whereby wee maye avoyde $\&$ shame all treasons $\&$ trecherous attempts, \& all vnfaithfull combynations $\mathrm{w}^{\text {th }}$ plotters $\&$ deuisers of euill./

For, the danger of theyr societie is great; many honourable houses of antiquitie $\&$ renowne $\&$ auncient names haue beene vtterly subuerted thereby, $\&$ rooted out as yf they had neuer

been

\section{[p.] 3}

been; \& the innocent, \& ignorant persons not made acquainted with theyr purposes $\&$ intentes haue been brought in question being seene but to frequente theyr companyes supposing at $y^{e}$ 
least that they could not but see or heare somewhat thereof./

Also to be well instructed in the statutes and Lawes of this Land is very profitable and necessary, Whereby they may keepe themselues $w^{\text {th }}$ in the compas thereof $w^{\text {th }}$ out controlment or running into danger./

Also the wyse $\&$ wittie sentences of the philosophers ${ }^{19}$ being heathen men without the knowledge of vsed exercised

God are worthie bookes to be sometymes for recreation

For they exhort vnto vertue $\&$ dehorte from vice, whereby the excellent giftes of God may be magnifyed in them

These said exercises will establish substance of good matter in the mynde, $\&$ prepare noble men, \& gentlemen of good worth for worthy $\&$ great imployments, \& make them wyse \& able to vndergoe whatsoeuer great busynesse they shall take in hand, to the aduancement

of the

\section{[p.] 4}

of the Gospell \& comfort of $y^{\mathrm{e}}$ whole common wealth/.

A mynde thus furnished will thinke all tymes

$$
\text { of idte }
$$

ill bestowed in bookes $\&$ of playes, \& of all such fruiteless $\&$ vnprofitable matter $\mathrm{w}^{\text {ch }}$ will peruert \& carry the mynde from all goodnesse $\&$ is an introduction vnto all euill./

It is the vertue of the mynde $w^{\text {ch }}$ maketh the man, or the woman, $w^{\text {th }}$ out the $\mathrm{w}^{\text {ch }}$ they appeare as blocks, $\mathrm{w}^{\mathrm{ch}}$ haue eyes \& see nott, lyke ymages sett vp, in whome is no counsell nor fore casting of perills: such cannot but stumble vpon euery inconueniencie; $\&$ be buffetted on euery syde for want of Wisdome.

Which wisdome is gotten by continuall exercise 
$\&$ well spending the tyme (as is aboue sayed) $\mathrm{w}^{\text {ch }}$; should bee $y^{e}$ laboure of a mans whole lyfe, for euery daye bringeth forth newe experience./ All these things comming into my mynde, I thought good to set them downe vnto my daughter, \& her children, as familiar talke \& communicacion with them, I being dead, as yf I were aliue.I

And I doe therewithall hartily praye them to accepte thereof, \& of the whole booke of my meditations

\section{[p.] 5}

my

meditations, / $\mathrm{w}^{\text {ch }}$ hath beene the exersise of $y e$ mynde from my youth vntill this daye, euen with the zeale of my hart by the sweete confer= ence with God, \& his holy spirit, \& faith in Jesus Christ who brought them all into my mynde $\&$ gaue them vnto me from tyme to tyme./

Being all vnto me as Iacobs pillar, euen true testimonyes vnto my soule \& conscience of the loue $\&$ gratious presence of $\mathrm{God} \mathrm{w}^{\mathrm{ch}}$ neuer forsooke me in all my dayes. Whereby I am encouraged stedfastly to belieue that he will same

be the , god vnto me for euer./ And though I think measure of ${ }_{n}$ None can take that ${ }_{\wedge}$ comfort in these meditations, which yet

as I my selfe maye doe, but Whosoeuer readeth seeing them may make good vse of them, especially then they shall fynde euery poynt of doctrine confirmed and approoued by the Scriptures.I

Which yf it please them to pervse, they shall fynde which

that profitt $\&$ consolation therin as they could not haue Imagined.

Which effect \& blessing of God I beseech him to giue vnto this booke, that the spirit of God maye 
joyne with euery one that readeth the same with

diligence

[p.] 6

diligence \& a zealous hart; $\mathrm{w}^{\text {ch }}$ maye make this booke vnto them as it is vnto me, euen lyke Iacobs piller a testimony of the loue \& presence of God, Who be with them for euer, \& increase, \& multiplye the giftes of his holy spirit in them, to the perfection of a good lyfe in this worlde, \& euerlasting blessednesse in the kingdome of heauen./

He that will take profitt by this exercise must turne awaye his eyes from beholding of vanitie and consider well what he heareth.

Shall the porter keepe out the thiefe Who often tymes commeth not onely to steale, but most cruelly to murther also?/

And is there no spirituall power within vs to resist the spirituall thiefe \& Cruell murtherer, who seeketh to destroye vs both soule $\&$ body? yes, Take heede, watch, $\&$ praye agaynst the lusts of the flesh, the lusts of the eyes, \& the pryde of lyfe, \& retayne not a thought of them in your hart.l

For When lust hath conceiued it bringeth forth sinne, $\&$ sinne when it is finished, it bringeth forth death./

Therefore let the word of God (aboue all) dwell in your hartes plenteously with the feare of God, \& est faith in Christ Jesus, Who is that strong ${ }_{\wedge}$ man, and hee will preserue vs from the spoyler that he shall neuer come neere vs to hurt vs./

As Idolatry

[p.] 7

swearing

As Idolatry, Witchcrafte, Murder, adultery lying, \& forswearing, pryde, ambition, couetousnesse slander $\&$ backbyting, rancour \& reuenge, \& such lyke./ 
Woe to that man in whome is found all these euills! a man may saye that a Legion of deuills possesseth his hart; the least of these sinnes is able to ouerthrow kingdomes \& thrones of the mightie.

These are the seedes sowen by the enuious man, $w^{\text {ch: }}$ will

can neuer bring forth good fruite, yet must they grow vp togither with the wheat vntill the generall Haruest; mans hart being more apte, \& capable by nature to retayne this wicked seede, then the seede of righteousnesse./

fore

Whereby all men must take heed how they trust too much in theyr owne strength, to thinck they maye keepe company with the wicked, \& fashion themselues vnto all vanities with the worlde, $\&$ thinck that they maye giue free libertie to theyr eyes to behold $\&$ gaze vpon all euill objects, \& to theyr eares

a

to he ${ }_{\wedge}$ rken $\&$ inclyne vnto all euill inducementes ing

\& prouocations; forgett ${ }_{A}$ that the hart of man is deceiptfull aboue all things, \& that they maye be snared thereby.l and

Rejecting that holy doctrine in the first psalme ${ }^{20}$ which teacheth vs not to walke in the counsell of the vngodly nor stand in the waye of sinners $\&$ nor sitt in the seate of the scornefull.

But to

\section{[p.] 8}

But to delight in the lawe of the Lorde, and ourselues

in his Lawe to exercyse himsetfe daye \& night

That man is in a woefull state who knoweth these things, \& yet runneth wittingly \& willingly therevnto; he can expect no good successe nor happy end; but mischiefe followeth him whither soeuer he goeth, \& will not leaue him vntill his vtter destruction be effected:/ 
It is certayne that there is a foundation \& ground many great

of much ensueing euills, That is to saye, When the nobilitie \& great personages from the highest to the to haue noe regard nor forecast what gouernours they sett ouer theyr children, nor what seruants they appoynte to attend vpon them./

Whereby it commeth to passe too often \& too vniuersally, that the myndes of chidren [sic] are taynted \& Corrupted, eorrupted euen from theyr infancie \& made capable of euery lewde \& euill conuersation, $\&$ are made impudent $\&$ bould, without all shame, $\&$ so stiffe-necked $\&$ peruerse therein, that no example or reproof counsell can restrayne them./

Many Gentlemen, \& theyr wyues are desirous to place theyr sonnes \& daughters in Honorable seruices, but they

\section{[p.] 9}

but they take no care to furnishe theyr myndes with true religion \& vertue, \& other good partes fitt for such preferrement

But yf they were put off \& not receiued into seruice for want of better education; euery one would endeavoure to amend that fault least theyr children should lye vpon theyr hands vnpreferred: Whereas otherwyse they would be sought for and enquired after, \& whosoeuer should retayne them would thincke themselues happy./

I had experience of a Gentlewoman ${ }^{21}$ (Neece vnto my Father, \&) brought vp by my mother from her chyldhood, whom after-ward she trusted to be gouernour ouer her owne children./

$\&$ She proued very religious, wyse, , chaste, $\&$ all good vertues that might be in a woman were constantly settled in her, (for, from her youth she made good vse of all things that euer she did read, see, or 
heare; \& obserued all companyes that euer she came in, good or badd: so that shee could giue a

$$
\text { most }
$$

right censure $\&$ true judgment of amy things, \& give wyse counsell vpon any occasion/

And she could apprehend, \& contriue any matter whatsoeuer propounded vnto her, most juditiously, \& sett her mynd indited

downe in wryting either by letters ${ }_{\wedge}$, or otherwyse as well as most any well as most men could haue done

She had

\section{[p.] 10}

She had (also) good knowledge in phisick \& surgerie./

She was of an excellent quicke spirit, \& pleasauntly conceited, so that she wonn my eldest Sister \& mee to be in loue with her, and to delight in all her speaches $\&$ actions/ for her mirth was very sauory $\&$ full of witt, $\&$ in her sadnesse she vttered forth nothing but wisdome \& grauitie/

She scoffed at all dalliance, ydle talke, \& wanton behauiour, appertayning therevnto, with a touch of a caueat to take heed thereof.

She counselled vs when we were alone, so to behaue our selues as yf all the world did looke vpon vs, \& to doe nothing in secret whereof our conscience might accuse vs, $\&$ by any meanes to avoyde the company of Seruingmen, or any other of lyke disposition,

$$
\text { gestures }
$$

whose ribald talke \& ydle thspositions and euill suggestions, were dangerous for our Chaste eares and eyes, to heare $\&$ behold, least the innocencie, and virginitie of our tender hearts should be stayned thereby./

And further shee aduised vs to deale truely and faithfully in all things both in worde \& deede, in small matters \& in great; $\&$ to beware of all lyes, 
$\&$ of Oathes, \& of reporting of newes, To heare much \& speake little, seeming to be ignorant in some things rather then to boast of the knowledge

which we

\section{[p.] 11}

to

Which we haue not, \& thereby ${ }_{\wedge}$ discouer our folly, \& giue occasion to be laughed att./

I delighted so much in her company that I would sitt with her all the daye in her chamber, \& by my good will, would neuer goe from her, embraceing alwayes her rebukes \& reproofes./

And when shee did see me idly disposed, shee would sett me to cipher with my penn, \& to cast vp and prooue great summes $\&$ accomptes, \& sometymes set

\section{a}

me to wryte, some supposed letter to this or that body concerning such \& such things, \& other tymes set me to reade in $D^{r}$ Turners Herball, ${ }^{22} \&$ in Bartholomew Vigoe, ${ }^{23}$ \& other tymes set me to sing psalmes \& somtymes set me to some curious worke (for she was an excellent workewoman in all kynds of needle worke, \& most curyously shee would performe it./

And when I was not $w^{\text {th }}$ her she would be sure to be with mee at my Heeles to see where $\& w^{\text {th }}$ whome I was, \& what I did or spake, such was her honest $\&$ faithfull care to performe the trust $w^{\text {ch }}$ my Mother reposed in her./

She gaue me warning of a gentlewoman who fre= quented my fathers house, to take heed of her, for that she was of a subtill spirit, full of wordes and questions, \& of an vndermynning disposition, a busy body

\section{[p.] 12}

busy body, \& a medler in matters $w^{\text {ch }}$ concerned her not, Neither regarding what hurt or trouble 
might redound

to many thereby, nor how my reputation might

be brought in question by conuersing with her, for she sought much into my company

(And surely this counsell of hers which she gaue me was very sweete, $\&$ good to be obserued, for in myne owne experience I haue found the danger very great. For ${ }^{24}$ such a busy body as this of whome his godly gentlewoman hath spoken, hath not lett of things by them committed worthy of blame to speake to me of things concerning other men, where= by the speaker might come to much trouble \& blame,

$\&$ then at her pleasure report (or rather aectuse me) to the partie of whome she spake (yf not to othersatso) that it was I that spake them to her./)

Also there was a gentleman of great accompt sitting at my fathers table, who spent all the dinner tyme in arguments \& much talke, wandring in his discourses./

So when dinner was doone she asked me yf I did not obserue the same, \& how he gloryed in his owne witt, \& to heare himselfe speake, $\&$ how his wordes were many but litle

then true substance of the matter, so that yf he were so wyse (as he tooke himselfe to be) she would judge him to be the wysest man in the kingdome.

Also there was a man \& a woman both maryed, but not man \& wyfe, of impudent behauiour one towards

\section{[p.] 13}

another; which when she behelde, she asked me yf I did not thincke it a monstruous spectacle to behold:

$\&$ wished me to make one staffe ${ }^{25} \&$ shee would make an other, vntill there were foure or fyue verses made therevpon, which she performed all herselfe, very wittily \& sharpe against such licentious beha= uiour, And this shee did for myne instruction to take heed of the lyke, \& to abhorre \& despise the same./ Also she aduised me to avoyde such company by 
all meanes possible, \& to take heede of whome I receiued any giftes, as a booke wherein might be written some wordes whereby I might betraye my selfe vnawares, or gloues, Apples or such lyke: for that wicked companions would euer presente tre= cherous attempts/, which afterwards I found true in some sorte, \& remembred her counsell./

Also that I should euer cary with mee, a modest eye, $\&$ a chast eare, a silent tongue, $\&$ a considerate heart, wary $\&$ heedfull of my selfe in all my wordes \& actions./

And in this \& such lyke manner shee wrought all these

her counsells vpon me from tyme to tyme./ in all other,

things \& many ${ }_{\wedge}$ more then I can here recite, $w^{\text {ch }}$ she thought profitable for me to remember $\&$ be instruc= ted in, whereby she sent me furnished into the worlde./

\section{[p.] 30}

This book of my Meditations

is the consolation of my soule, the joye of my hart \& the stabilitie of my mynde./

As they are approued by the word of God, $\&$ as I doe approoue them in myne owne conscience by the same word:

o

And I haue not sett them downe for attstentation or vanitie, as God himselfe is witnesse but with the zeale of my hart./

\section{Knowing}

\section{[p.] 31}

Knowing that there is nothing hath happen= ed vnto me in the course of my lyfe, either in prosperitie or aduersitie in any kynde, what= some

soeuer, but the lyke maye fall out to any other, wherein my comforts \& remedies may be approued 
vnto them as they haue been vnto mee./

Hartily praying euery faithfull reader thereof to accept my good meaning therein", and give a

*And my self will say $w^{\text {th }}$ the prophet Dauid.

psalm 119: Accept, I beseech thee etc:

$\&$ mild patient, censure $\mathrm{w}^{\text {th }}$ meekenes, not looking for exact

Eloquence, Method, or learning, $w^{\text {ch }}$ could not proceed from me who have not been trained vp in vniuersitie

Learning, \&

have had most experience of myne owne weaknes ignorance, \& worthinesse [sic], euer humbled vnder the hand of God who hath been my greatest Comfort.I

\section{[p.] 32}

Myne owne obseruation of Sir Walter Mildmay, hauing been with him almost twenty yeares vprysing and downelying in his house, who was wyse eloquent $\&$ methodicall in all his speaches which proceeded from a cleere judgem ${ }^{t} \&$ true grounded discerning of whatsoeuer he spake of, $w^{\text {th }}$ the applause of all men that heard him /

First touching matters of comon wealth, wherin he (being chosen by his country) had a place \& voyce to speake betwixt the Queene of England his Mistresse \& her subiects in divers Parliamentes: ${ }^{26} \&$ by his place of chancellour of the exchequer to speake betwixt one man and

another, yea concerning $y^{e}$ Queene $\&$ her subiects touching Reuenues./

these

In all hich he shewed himselfe most faithfull equall \& just, \& carryed all matters $w^{\text {th }}$ the contentm ${ }^{t}$ of all parties./ tation $\&$ glory of the world, \& $w^{\text {th }}$ out enriching 
rents

of his owne estate by the Queenes her Lands

or treasure

[p.] 33

in

or treasure, whereof he might with a safe con= science washe his hands in innocencie. P $^{7}$

Though he did see many abuses wherein the Queene \& state was wronged by greater men then himselfe put in trust, which example he might haue followed as well as they.

But that he did detest $\&$ abhorre from his hart such false $\&$ wicked dealings, $w^{\text {ch }}$ could expect from God no blessing in the end./

He euer perswaded the Queene his soueraigne, in such a gratious manner to demaund all her duetyes seruices \& obedience from her subiects as they might yeeld all, \& more then they were well able vnto her $\mathrm{Ma}^{\text {tie }}$ rather in loue $\&$ faith= full harts towards her then by constraint or taw violence viotenee to be vrged from them./

And also hee would say, he euer found it the best meanes to perswade her subiects $\mathbf{w}^{\text {th }}$ argum ${ }^{\text {tes }}$ of reason, \& loue, whereby they might rest assured of her Maties loue \& tender affection towards them as a Nurse \& Mother of her Common wealth rather then by harsh \& distastefull speaches to stryke theyr harts with a doubtfulnesse of her loue $\&$ care of theyr estates./ . . .

\section{[p.] 35}

In his owne priuate house, his houshold \& family $\&$ all sorts of people that resorted vnto him, did admire his innocent \& vnspotted caryage of him selfe amongst them in all his words \& actions ready to doe euery man good, \& hurt to no man./

He was a very pleasant conceipted man at his 
good occasions, $\&$ give table: \& continually would minister ${ }_{\wedge}$ wyse and pro= fitable speeches to the great content of his seruantes $\&$ those that satt with him/

He would neuer suffer any man to be euill spoken off at his table by any man whatsoeuer, but he would cutt him off in his speech, \& reprooue him in a gentle \& good manner./

Neither would he suffer any of what calling soeuer he were, to talke at his table of high mat= ters of state, of the Queene, her counsell, nor of the nobilitie, vnreuerently; nor prophanely of God, but he would cut off theyr speach in such a wyse \& louing manner, that they euer tooke it in good parte, \& reuerenced him

He was to his power a great fauourer of all good learning \& of the true profession of $y^{e}$ Gospell, as appears faithfully to the world by $y^{t}$ flourishing religious

learned Emmanuel Colledge he gaue

founded, builded, laid in good measure endowed by him at his owne great charges/

\section{[p.] 36}

He gaue exhibition to diuers strangers who were men of learning, \& truely religious, he charged his owne land $w^{\text {th }}$ yearly stipends to two Colledges in Cambrige, \& buttded Emmantrell Colledge of his enarge. . $^{8}$

The worst man that euer repayred vnto him would speake well of him, \& confesse that they had cause to loue him./

Certaynly Whosoeuer he be that maketh himselfe an instrument to diuide the King $\&$ his subiects, deserueth, of them both, to be cast out $\&$ to be accurssed both of God \& mann.

It is a dangerous thing for a man to put his hand betwixt the barke \& the tree, according to the old prouerbe. ${ }^{29}$ 
But yf God in his wrath \& sore displeasure, towardes a sinfull kingdome or a wicked family, doe deter= mine theyr subuersion for theyr sinne, there can want no instrument or meanes to worke the same vntill theyr vtter confusion be effected.

us

Yet let not the lorde deale $\mathrm{w}^{\text {th }}$ according to our deserts from the highest to the lowest, but spare vs./ \& preserue vs in his mercy, neither let him take his word \& sincere ministration thereof from vs./

Whereby he

\section{[p.] 37}

whereby he dwelleth amongst vs, whatsoeuer punish= ment it please him to inflict vpon vs for our sinnes let him convert vs as our father in christ $\&$ abyde with vs for euer./

And the Lorde make it Good vnto our king \& his posteritie for euer vnto the worlds end, that they may fynde themselues happy princes, \& make theyr religious, /just

people happy subiects by theyr ${ }_{\wedge}$ gratious $\&$ louing gouernment by the direction of the Gospell of peace: \& the God of peace worke it euer in theyr myndes to make the same theyr joye \& tryumph did, to as dauid daunced before the Arke $w^{\text {th }}$ instrumentes of musick bycause the presence of God was figured therein ${ }^{30}$

And further I haue thought good to call to mynde the extraordinary loue \& fauour of this said worthy person towards my selfe in my tender youth./

Which loue was such that he desired me of my father, to Marry $w^{\text {th }}$ his eldest Sonne./ His Sonne being then more willing to trauaile to get experience of the worlde then to marry so soone, was vnwilling to giue eare therevnto./ 


\section{[p.] 38}

But his father told him, yf he did not Marry $w^{\text {th }}$ me, he should neuer bring any other woman into his house.

Vpon $w^{\text {ch }}$ importunatie of his Father, he was con= tent, \& entred into communication $\mathrm{w}^{\text {th }}$ him what Joynter he would make me, \& what allowance he would giue for our maintainance in his owne tyme

His Father answered him agayne by earnest protes= tations \& vowe in the presence of the Lady his Good mother, saying

Doest thou distrust me Anthony? here I speak it before God, yf thou marry with this woman I will give thee all that I haue, \& whatsoeuer els I can procure, shall be thyne./

And further If I doe it not, thy mother shall be a witnesse against me in heauen, expressing the same with teares: $w^{\text {ch }}$ moued the harts of him= selfe \& his mother to weepe also./

Wherevpon he yeelded vnto his father, \& $y^{e}$ marryage was concluded betwixt him \& mee vpon the trust of his fidelitie \& good hope that he would neuer alter his mynde nor breake his said oath $\&$ vowe, the consummation of that marryage being the seale of that bond./

\section{[p.] 39}

My father in lawe gaue me this posie in my

Maneat inviolata fides, $\mathrm{y}^{\mathrm{t}}$ is to say

Wedding Ring ${ }_{\wedge}$ Let thy fayth remaine inuiolate, which in the very instant of my Maryage I receiued most religiously, $\mathrm{w}^{\text {th }}$ a full resolution (by the grace of God) to performe the same vnto the end of my lyfe,

Wherein he bound me vnto his sonne as he had before bound himselfe vnto him vpon that condicion 
of our maryage.

After which, we liued $w^{\text {th }}$ him almost twenty yeares, receiuing no more maintainance from him

but abotre one $130^{\text {fi }}$ by yeare bare pention to paye our seruantes wages, \& to apparell our selues $\&$ to defraye all other charges whatsoeuer, $w^{\text {ch }}$ to suffice in any competency could not by any meanes possible performe $y^{e}$

to

teast parte of our necessities

For my husband followed our Queene Elizabeth her Court, \& was appoynted by her $\mathrm{ma}^{\text {tie }}$ to goe forth with etrery embassadours that went about any speciall busynes, $\&$ was imployed diuers tymes therein for his owne experience. $\beta^{11}$

Whereby he might be the better enabled to serue his prince \& Country at all opportunities \& occasions which he did

$\&$ all ^ vpon his owne charge $w^{\text {th }}$ out crauing any allowance

\section{[p.] 40}

allowance from the Queene or from any els, keeping men \& horsses answerable to such a course of lyfe as well at home as abroad

this

Which was a strange thing how he could doe $y^{\circ}$ same without running himselfe so farre in debtt

or a very great part of that all his Fathers Eand whole estate could not haue beene able to hate discharge the same. But God who can make a little goe ffarre, put into his mynde to remember, a tyme to spare \& a tyme to spend, which he did obserue in all his expences, wherein God reserued a blessing for $y^{e}$ future tymes; yet could he not but bee in debt, $\mathrm{w}^{\mathrm{ch}}$ he was./

And when his Father dyed, not long before his 
death, he diuided his land almost equally betwixt him \& his second brother \& lykewyse his Plate $\&$ houshold stuffe, \& left him no money or that not much ${ }^{\beta 2}$ And therewithall bound his portion of land by a perpetuitie, ${ }^{33} \&$ made me no joynter, but teft me to the thirds ${ }^{34}$ which might be troublesome \& veertayne, Neither did he leaue any sufficient portion for the perferrement of his onely chylde $\&$ daughter. ${ }^{35}$

My husband fynding himselfe so straytned that he could make me no joynter, nor giue his daughter any portion

\section{[p.] 41}

any portion nor make any states good vnto his but onely for his owne life, Tennanntes , for fynes receiued, nor paye his debts, nor ransome himselfe yf he should be taken pri= soner by some extraordinary occasion,

He sought to enlarge himselfe by the Parliam ${ }^{t}$ $\&$ propounded all these said poynts to that Hon= nourable Court. where they were receiued as things most reasonable $\&$ fitting to be yeelded vnto, both in nature \& conscience./

But his Brother would not by any meanes be per= swaded to giue his consent that the least tittle thereof should be graunted vnto him, though lesse then one halfe of my Husbandes Land would haue satisfyed all his demaunds, \& his Brother might haue confirmed the residue of his Land to himselfe $\&$ his posteritie by the Parliament.I

his

By which obstinacie \& euill nature of him Brother, the Parliament dismissed of the left off to take consideracion of it, leaving it to the lawe. Cause, $\&$ he constrayned to remayne still in his wants

Then he being thus provoked, aduentured to 
taile

sett himselfe at liberty by Cutting off the intate

$\&$

of his perpetuitie; which thing he did

performe by the Law of the Land,

provide
for mee and for my
Daughter, and
discharged all his
debts, to the good
contentment of us
and many other/

and according to in that thereby he was inabled and did tawtly by , the lawe of God, , the lawe of nature

$$
\& y^{\mathrm{e}} \text { law }
$$

\section{[p.] 42}

$\&$ the lawe of the Land, to the contentmen ${ }^{t}$ of all parties but his Brother \& his chitdren.l

All $w^{\text {ch }}$ the right hand of God hath brought

$$
\& \text { mercy }
$$

to passe in his vnspeakable loue towards vs and our posteritie (\& shall not wee remember? or shall we be ashamed to acknowledge \& confesse the same from generation to generation for euer?

God forbid. For, our thanckfulnesse for one benefitt is the crauing of another \& God alwayes accepteth a thanckfull mynd...

\section{[p.] 43}

Wherefore I leaue it vnto my whole posteritie for theyr meditiation \& consideration, that what falleth to one the lyke maye fall to another, and be that there can no euill nor troubles so great, but they maye turne to our good \& receiue a blessed end to them that keepe innocencie, \& take heede vnto the thing that is right; for that will bring a man peace at the last./

I thought my selfe in the house of God all $y^{e}$ tyme of myne aboad $w^{\text {th }}$ my father in Lawe: 
for that, no euill company was permitted to resort to his house nor to appeare in his presence, whereby I was preserued from the sight, or hearing of euill/

And nothing but good examples, \& good counsells, $\&$ continuall exercyse in the word of God was prefered vnto me

Wherefore

\section{[p.] 44}

Werfore [sic] I esteemed my selfe more happy to liue $w^{\text {th }}$ him (yf it had been but) $w^{\text {th }}$ bread and water then $w^{\text {th }}$ any other with a continuall feast./

The Lady his wyfe was also a vertuous woman $\&$ dutifull to her husband, in all chastitie, obe= dience, loue, \& feare towards him as euer I did knowe any, and she instructed me lyke= wyse to become a faithfull wyfe vnto her sonne Whereof there was great proofe made in all theyr tyme by many afflictions \& contrary occasions $w^{\text {ch }}$ fell out betwixt me $\&$ my husband $\&$ betwixt vs \& them./

My husband was much from me in all that tyme, \& I spent the best part of my youth in solitarinesse, shunning all opportunities to run into company least I might be inticed \& drawen awaye by some euill suggestions to stayne myne vnspotted garment, \& so be robbed of myne innocencie, for I durst put no confi= dence in my selfe for myne owne defence./ And some great personages, Ladies of myne acquaintance would perswade me to goe with them to the Court, to feasts Mariages \& playes

saying, $\mathrm{y}^{\mathrm{t}}$

\section{[p.] 45}

saying, that it was pittie, my youth should be swallowed $\mathrm{vp} \mathrm{w}^{\text {th }}$ out all pleasure or delight in the world/ 
Myne answere was that God had placed me in this house, \& yf I found no comfort here, I would neuer seeke it out of this house; and this was my certayne resolution./

And as I gaue my selfe wholly vnto God, in the sinceritie of my hart so he receiued me gratiously, \& preserued me in safetie, \& directed $\&$ prospered me in all my wayes, \& left me not comfortlesse but put into my mynde many good

all-

delights wherein I spent my tyme most continually/.

First in diuinitie euery daye as my leisure would giue me leaue, \& the grace of God, per= mitt $\&$ drawe me. I did read a chapter in the bookes of Moses, another in one of the prophetes one chapter in the Gospells, \& another in the Epistles to the end of the reuelation, \& the whole psalmes appoynted for the daye, ending $\&$ beginning agayne $\&$ so proceeded in that $\mathrm{g}$ course

Wherein I found that as the water pierceth often

the hard stone by ${ }_{\wedge}$ dropping therevpon; So the continuall exercyse in the word of God, made

a deepe

\section{[p.] 46}

a deepe impression in my hart stony hart, $\mathrm{w}^{\text {th }}$ an apteness to inclyne vnto the will of God, \& to delight in the meditiation therof vpon euery occation of thoughtes arysing in my mynde, or vpon whatsoeuer myne eye did bohold [sic] or myne eare did heare, applying the same as I was directed by the spirit of God./

Which sayed 5...r course was the onely stabilitie of my mynde, \& my staye \& Comfort in all the troubles \& calamities of my whole lyfe/ Also euery daye I spent some tyme in playing 
on my lute, \& setting songs of 5 partes therevnto \& practised my voyce in singing of psalmes/, \& in making my

^ prayers to God, And confessing any sinnes $w^{\text {ch }}$ were euer ready to meete me in euery thought $\&$ to turne me awaye from God \& from all goodnesse./

For the more a man inclineth himselfe to vertue $\&$ to depart from euill, the greater will be his temptations; \& ydlenesse is $\mathrm{y}^{\mathrm{e}}$ deuills opportunitie./

Also euery daye I spent some tyme in the Herball ${ }^{36}$ $\&$ bookes of phisick, $\&$ in ministring to one or other by the directions of the best phisitions of myne acquaintance $\&$ euer god gaue a blessing therevnto./

Also euery

\section{[p.] 47}

Also euery daye I spent some tyme in workes of myne owne inuention without sample of drawing or patterne before me for carpett or Cushion worke $\&$ to drawe flowers \& fruites to theyr lyfe $w^{\text {th }}$ my plummett ${ }^{37}$ vpon paper.l

All which varietie of exercises did greatly recre: ate my mynde; for I thought of nothing else but that I was a doing in euery perticuler one of these said exercises./

And though I was but meanly furnished to be excellent in any one of these exercises, yet they did me good, in as much as I found in my selfe that God wrought $\mathrm{w}^{\text {th }}$ me in all./

And further, betwixt the tyme of my father in law his death, \& the cutting off of the said perpetuitie, our Daughter was to be giuen in Maryage, \& her father had no portion to giue her, wherevpon I gaue her all my present possession of myne owne whole inheritance being the flower $\&$ best parte of my portion, My husband hauing his lyfe in it also./ 
vnto me

Then was there nothing left for my securitie but the other part of my portion of inheritance contayned in my Mothers joynter $w^{\text {ch }}$, was questionable $\&$ to be recouered $w^{\text {th }}$ much suites in Lawe after her death

So that

\section{[p.] 48}

So that yf my husband had dyed at that tyme, I should haue had no Land but the bare rent of about some $300^{\text {fi }}$ by yeare, not suffitient to keepe any house to maintayne the calling of my fathers daughter nor for my husbands wyfe.

Neither could I haue been able to contend by lawe with my husbands brother for my thirds, ${ }^{38}$ nor $\mathrm{w}^{\text {th }}$ my Sister for the right of myne inheritance where= vnto she layed claime. In all $\mathrm{w}^{\text {ch }}$, my state in myne age stood vpon Hazards.

My husband in a due consideration thereof, and in his good nature \& thankefull mynde vnto me for my. extraordinary loue to his daughter, thus to

$$
\text { of }
$$

dispossesse my selfe for her sake $t \&$ his owne, so great a portion) whereby I might haue put my selfe into great want \& disgrace in myne age) made great hast to breake \& cut off his perpetuitie, fearing he should not liue to performe the same.

At which tyme when he went vp to London about this busines \& finished it, I knewe nothing thereof, but at that very instant I made meanes vnto him, that he would be pleased to repayre the Parsonage at Oundell wherein I had my lyfe that I might haue an house to goe vnto \& to convay my stuffe, vpon any sodayne occasion that might befall me

[p.] 49

(for my Husband was then very sicklye) with 
this resolution, to spend my whole lyfe in that place in the most priuate manner possible, ${ }^{39} \&$ neuer to haue lived with my daughter or to be beholden vnto her or to any other friend whoso= euer; with great contentation of mynde, and mortification to the world

without repentance of whatsoeuer I had giuen, wishing it much more with the abundance of

and to her worthy \& honorable Husband, who deserved the same, Gods blessing there $w^{\text {th }}$ to my daughter ${ }_{\wedge}$ and their Children./

Often tymes I haue prayed to God that yf it were his pleasure that I should be cast out of this house in myne age by my Husbands brother, yet that he would be pleased to goe out $\mathrm{w}^{\text {th }}$ me as he came into this house with me, \& brought me hether, $\&$ hath guided me $\&$ directed me in all my wayes all the tyme of my being here.l

And then let his will be done; so be it vnto me $w^{\text {th }}$ a cheerefull \& good hart let me goe out willingly $\&$ his faithfullnesse $\&$ truth be my shield \& Buckler for euer.l

Nothing can be sodaine or strange vnto vs, neither can we sustayne want though we haue nothing, when God is with vs: our hartes being established with faith in him, \& in loue patience meekenes \& temperancee, euer wayting vpon the will of God, to

weepe

\section{[p.] 50}

weepe or rejoyce, to haue or not to haue, as it best pleaseth him./

I haue often tymes sayde vnto my soule in the secret of my hart; God forbid that I should so much wishe or desyre to dwell in this house during my lyfe or to possesse the Lands \& provisions belong as

ing therevnto, butonety that God would be pleased much rather to hold me in myne inte 
gritie \& faithfulnes towards God \& my husband./

Then God looked vpon me \& gaue me those earthly blessings $w^{\text {ch }}$ I asked not nor deserued neither could expect; the preseruation of my husbands lyfe being a principall meanes thereof, which God alone perfor= med for me When he deliuered him in many dangers \& perrills of his lyfe./

Wherein I haue found \& proued that it is good to depend wholly vpon God with a good conscience $\&$ the true testimony of the spirit of God to witnesse with vs $\&$ for vs.

And further I must not let slippe out of my mynde What God hath done for me in myne owne perticuler inheritance wherevnto I was lawfully borne My father,

Sr Henry Sharington of Laycot in Wiltshire Knight, then living

Had onely three daughters ${ }_{\wedge}$, and vpon

\section{[p.] 51}

vpon our Maryages he diuided his land into three partes, \& intailled the same vnto vs $\mathrm{w}^{\text {th }}$ a perpetuitie

It happened that our Eldest Sister dyed that lived $\mathrm{w}^{\text {th }}$ out children, $\&$ her part was to be diui= ded betwixt me \& my younger sister according to the words in the conveyance \& according to of our marryage the Articles of the Couenantes, so intended ${ }^{40}$ Yet not- $w^{\text {th }}$ standing when my father dyed he was perswaded to alter his mynde, \& to breake his courenant towards me, \& to forget that my sister \& I proceeded both from one father $\&$ from one mother, \& that I had euer beene his obedient $\&$ louing daugh= ter, \& that I had neuer prouoked him to toward him displeasure by any misdemeanure ${ }_{\wedge}$ any waye. 
But God did behold myne innocencie, and my naturall \& faithfull hart to my father, and forgatt it not according vnto the scriptures Though my father \& my mother forsake me, yet the Lord will gather me vp, And how the Lord hath made good his word vnto me, $\mathrm{He}$ knoweth \& I haue approued./

For My Father lying on his deathbed eatted

for a

[p.] 52

by name, Judge Meade:

did before a judge, before revoked his said for= mer conveyance, \& established another, wherein sister

he gaue my ${ }_{A}$ two third parts of his best Land $\&$ gaue me but one third parte of his worst land./ I

And Comming to visit my father not thinking to fynde him so neere his end (for his great danger in his sicknesse was kept from me) I was brought into his chamber vpon a sodayne at the very instant when the judge was there, $\&$ those abou accompa= nying him $w^{\text {ch }}$ were plotters, \& workers of this vniust alteration, \& vpon the sight of mee they scattered one from another \& put away the bookes and parchmentes:/

As soone as I had done my duety to my Father I was caryed out of his presence into another Roome where there came to me my Mother, my one after another Sister, \& myne vncle my mothers Brother ${ }_{A}$ to per= swade Mee \& to comfort me in my sorrowe for my Father, that he was my good father \& loued me \& that all his care was for mee more then for my sister: wherein I was innocent \& suspected no iniury towards me, my conscience bearing me witnesse that I neuer deserued the same./ At $w^{\text {ch }}$ tyme I desyred to watch with my Father 
\& to lye in the House: but I could not be permitted therevnto vntill they had effected all that

\section{[p.] 53}

all that busynesse in Hand \& after that, I laye in the house \& was entertayned in all kindenesse as though there had beene no such matter \& all well with mee /

$$
\text { ed }
$$

And I intreating them to put my father in mynde to be good vnto his old Servants, \& to $y^{\mathrm{e}}$ neerest of his bloud \& kindred who stood in neede thereof, \& also to remember some friends of

his vnto whome he was beholden for many kynd= nesses, which friends also combyned themselues against mee in this Conspiracye

Wherein they requited me euill for good, and hatred for my good will: whereof God was witnesse, \& turned his louing countenance towards me.l

And when my father drewe nearer $\&$ neerer towards his end, the pangues of death appearing in his face, \& I kneeling downe by his bed syde weeping at the viewe therof: he looked sternely vpon me \& shooke me hard by the hand saying Oh Grace, Grace, Grace. I praye God blesse thee, thou shalt haue much trouble with thy land I tell thee, but I praye God thou mayest well ouercome it./

\section{[p.] 54}

These were his last wordes vnto me, wherein assuredly, the blessing of God was included.

And sometyme in his fitt of the stone, he was heard to saye; oh that it were to doe agayne./ After my father was dead; my sister came to mee, \& said, my Father hath set out our portions 
$\&$ the bookes are drawen that each of vs may take our part, $w^{\text {ch }}$ is, you haue onely that third which was myne, \& I haue that parte $\mathrm{w}^{\mathrm{ch}}$ was giuen vnto you, $w^{\text {th }}$ that other part also $w^{\text {ch }}$ was allotted vnto our eldest sister, \& I would my brother Mildmay would come \& take his part. ${ }^{41}$

And I answered her, that I thought he would not loose his parte for want of taking it when he did see his tyme./

Then further I asked her, And is it so indeede that my father hath dealt thus with me who neuer offended him willingly, but euer sought to please him in all things with as much duety and loue as any chyld he had?/

Yf God moued him therevnto without any indyrect dealings by your Husband, your selfe, or any other friends for you; then, the will of

God be

\section{[p.] 55}

God be done, I beseech him to giue his blessing there= $w^{\text {th }}$ all; \& my small portion shall content me as well as your great portion shall contente you./

But yf you haue laboured my father by all meanes to worke, \& bring to passe this vnnaturall wrong towards me, I commit my whole cause into the hand of God, \& doe most earnestly desyre him to be judge betwixt you $\&$ mee, $\&$ to right $\&$ defend my Cause.I

Then went I into a place by my selfe alone, $\&$ powred out my hart vnto God with abundance of teares, confessing myne vnworthynesse of $y^{\mathrm{e}}$ least part, \& after I had committed my care vnto God, my mynde was satisfyed \& neuer troubled after./

And after the funerall was ended, my father in Sr Walter Mildmay

Lawe ${ }_{\wedge}$ caused diligent search to be made whether that 


\section{returned}

said last conveyance were lawfully entred into the and inrolled there

court of recorde ${ }_{\wedge}, \&$ it was found that my father

$$
y^{t} \text { his }
$$

did not liue out the tyme to make out the last deed.

good in Lawe: wherevpon there was exceptions taken

therevnto, \& the matter was so effectually followed, that

very next after

within the same terme ${ }_{a}$ therein that last convayance

was made, it receiued an absolute ouerthrowe

by Lawe, \& the first conveyance stood good in his

former force.l

Then when they did see this parte of theyr hope

frustrate, they gaue it out that they had another

$$
\text { string to }
$$

\section{[p.] 56}

string to theyr bowe, $w^{\text {ch }}$ was, that my father had made a Lease of that land contayned in that last conveyance, vnto my said sister for a thowsand yeares.I

Wherevpon my father in Lawe instantly called those wordes in question./

\section{Sisters first}

And some reasonable tyme after my fathers death

or

Husband dyed she assured her selfe \& was marryed to her second Husband, ${ }^{42}$ by whose meanes she was fallen into great trouble: where vpon she was constrayned to make sute to my father in law as to her onely friend on whome she did wholly rely, and he performed all things to doe her good, \& helped her out of her troubles, \& was vnto his dying daye her most faithfull friend./

Not $w^{\text {th }}$ standing he had heard of the speeches be= twixt her \& her first Husband a little before his death, for he perswaded her to be content, \& to give me leaue to enioye me portion equally with her, for as much as there was ynough for vs both saying 
it was pittie I should be wronged, for that I had not deserued it, or words to this effect./

Wherevnto she answered, doeth thy hart faile thee now? I willbe drawen in pieces $w^{\text {th }}$ wyld horsses before euer I will yeeld vnto her./

$$
\text { in this her trouble }
$$

But howsoeuer her mynde was then^; she gaue con= sent that this said Lease for a thousand yeares comel a

should be put to , tryall in Lawe, $\&$ so the sute

proceeded, \&

\section{[p.] 57}

proceeded, $\&$ the said lease receiued a judge $=$ ment, \& was canselled by order of Lawe/

Yet when my father in lawe was dead, they gaue it out that they hoped to bring the matter aboute to another tryall, $\&$ to ouerthrowe that judgem ${ }^{t}$ after my mothers death.I And when my mother was dead, my sister fortifi= ed the house to keepe me out by force, \& kept her possession of all the lands, but onely that part of myne conteyned in my mothers joynter $\mathrm{w}^{\mathrm{ch}}$ my Husband held by force against her./

also

My Husband ${ }_{A}$ told her that it were good for vs both to end this chargeable course in the beginning wherevnto she answered that she would be torne in pieces $w^{\text {th }}$ wylde horsses before she would give ouer./

But after a whole yeares expences \& charges in this busynes, God did put it into my sisters mynde equall

to yeeld vnto an eagalt partition \& diuiding of our portion betwixt vs: $w^{\text {ch }}$ was performed accor= dingly to both our great Contentes, all strife end= ed, natural loue reuiued $\&$ Confirmed, $w^{\text {th }}$ all well wishing to each other, \& our posterities as to our selues euen from our harts: all $w^{\text {ch }}$ was $y^{e}$ worke of God expressly. For who could haue reconciled vs in loue and peace but God? euen the 
same God which worketh all things for the best for his children./

This hath

\section{[p.] 58}

$$
\text { a great part of }
$$

This hath beene ${ }_{\wedge}$ the pilgrimage

of my whole lyfe: wherein God hath been euer with mee, in all companyes at all tymes $\&$ places opportunities \& necessities, setting himselfe as it were in person, against all myne opposites in theyr strong \& strange oppositions; for they were fathers my Sister and her Husband and their frends for them, working my \& thought they might doe wh theyr owne what they father and mother therunto against mee: would right or wrong to theyr children being theyr subiects

But God the lord of lyfe \& father of our fathers preuented $\&$ frustrated theyr purposes when 24 houres of tyme when he purposed to hatre confirmed [?] my wrong he cut off my father $\&$ suffred him not to liue to doe me hurt; $\&$ when he preserued the lyfe of my Husband in many extraordinary \& great dangers to doe me good, \& when my sisters hart was hum= bled by the great troubles $w^{\text {ch }}$ God layed vpon her after her first Husbands death, \& in the mean tyme the Lorde so ledd \& carryed me in all my wayes $\&$ preserued myne innocency so vnspotted in theyr sight, $\mathrm{y}^{\mathrm{t}}$ they could not accuse me in the least cryme: yet I am not thereby justifyed before God.I

For yf I had been vnduetyfull to my Husband, or \& vnduetyfull

disobedient ^ to my parents, $\&$ giuen to a wicked course of lyfe \& conversation, God himselfe would haue forsaken me, \& taken all his graces from me, $\&$ haue deliuered me vp vnto the will of myne $\mathrm{ad}=$

\section{[p.] 59}

myne aduersaryes, $\&$ all good friends and meanes 
would haue turned against me./

But all men seeing God to take my parte, pittied me \& wished me all good successe, $\&$ gaue me theyr best furtherance, \& specially those men in place best able to doe me good. for I was euer beloued of att good men, \& conuersed most $w^{\text {th }}$ them, \& that was the gratious gifte of God who also kept all wicked company from mee.l

And I haue euer approued it the best waye to keepe innocency to avoyde \& shunn all euill Company, \& to hate, abhorre $\&$ detest all wicked= nesse, $\&$ all the shewes $\&$ appearances thereof./

And how should wee chuse the good \& refuse the euill? but by the spirit of God $w^{\text {th }}$ in vs: $w^{\text {ch }}$ is $y^{e}$ onely Gifte of God \& the true testimony of his gratious presence./

much much

I haue etrer beene, trayned vp by God himselfe in his Schoole of adversitie, whereby I haue beene humbled before God, \& in myne owne sight, so that I could not saye, this I would haue or that I would doe, but at the pleasure \& will of God in all things.

Neither did I behold vnworthynesse in any other but in my selfe, nor desyre to please my selfe be= fore others, nor to preferre vanities \& transitory things of this world before the dilygent exercyse

\section{in the}

\section{[p.] 60}

in the word of God, w $w^{\text {ch }}$ endureth for euer/

God hath (from the beginning of my lyfe) layed bitternesse vpon all my pleasures \& delightes of earthly things, whereby my mynde was mortifyed from them, \& the desyres of my hart the more inclinable to heauenly things, with the more patience to beare all crosses, knowing $\mathrm{y}^{t} \mathrm{y}^{\mathrm{e}}$ determination thereof was in the hand of God $\&$ that he afflicteth not for euer 
God doeth knowe my naturall inclination vnto euill from my birth \& myne aptnesse to runn the waye him

of the wicked from God \& all righteousnes: where= fore $\mathrm{w}^{\text {th }}$ his rod $\&$ sheepheards crooke he hath and kept gathered ${ }_{\wedge}$ me vnto him selfe, blessed be his holy name for euer.

For all these myne afflictions haue beene better vnto me \& haue done me more good then all the treasures of the earth could haue done: for they all perishe \& come to nothing, but the even in his corrections loue \& mercy of God abydeth for euer./

We are debtters, not to the fleshe to liue after the flesh. For yf wee liue after the fleshe we shall mortifie $y^{\mathrm{e}}$ deeds of $\mathrm{y}^{\mathrm{e}}$ flesh by dye, but yf we titue after the spirit, we shall liue for as many as are led by the spirit of God they are $y^{\mathrm{e}}$ sonnes of God./

Yf wee be children, we are also heires, euen $y^{\mathrm{e}}$

heires

\section{[p.] 61}

heires of God, \& heires annexed $w^{\text {th }}$ Christ, if so be that we suffer $w^{\text {th }}$ him, that we may also be glorified with him./

For I count that the afflictions of this present tyme, are not worthy of the glory that shall be be shew= ed vnto vs.

Also we know that all things worke togither for the best vnto them that love God, even vnto them that are called of his purpose

What have I gayned by the troubles of my whole lyfe? even that $w^{\text {ch }} I$ have learned (that is to say) to put no con= fidence in man nor in any Childe of man, nor in any earthly things $\mathrm{w}^{\text {ch }}$ are all changable \& vncertayne, and there is no truth in them, according to the Scriptures, all men are lyars, even the best of them./ 
All men by corrupt nature are apte to provoke and offend one another, as Parents theyr Children, \& Children theyr Parents; Husbands theyr wyves \& wyves their Husbands. Masters their Servannts, \& Servants their Masters. Wherevpon there aryseth such strife and Contention as though they could never be reconciled

But if every one were instructed in theyr dueties one towards another, $w^{\text {th }}$ the feare of God in theyr harts, exercising those vertues of meekenesse, temperance, patience, Chastitie, love \& obedience; the spirit of God would never leave them vntill a peace were concluded betwixt them.I

\section{Finis/}

\section{[p.] 78}

The Authors Meditation vpon Her Corps

Let me behold my corpes wch lyeth folden in sear= clothes, Leaded \& Coffined here before me yet vnburyed; \& consider, he was as I am, \& as he is, I shall be,/

His candle is put out, his fyre is quenched, $\&$ he hath made his bed in the darke, the grasse is mowen, the seed falleth into the earth $\&$ shall ryse agayne

And therew ${ }^{\text {thall }}$ let the eyes of my soule be lifted vp vnto our Lorde Jesus christ, sitting at the right hand of God his heauenly father who was dead $\&$ buryed $\&$ arose agayne the third daye: $w^{\text {th }}$ this assurance $\&$ stedfast faith that the same spirit $w^{\text {ch }}$ raysed christ from the

$$
\text { graue }
$$

\section{[p.] 79}

graue, shall rayse my Corpes, \& make vs both parta= kers $w^{\text {th }}$ himselfe of a ioyfull resurrection at the last daye./

In this worlde (is to be looked for) nothing but death; $w^{\text {th }}$ Christ, lyfe; here nothing but weakenesse, $w^{\text {th }}$ him strength. here a short tyme soone ended; $w^{\text {th }}$ Christ tyme $\mathrm{w}^{\text {th }}$ out end./ 
And though Christ be exalted in his glory; yet his eyes doe behold our corpes, dust, \& dry bones:

Prouidently disposing them vnto the daye of resurrection, as the childe after conception is framed in the wombe vnto the daye of birth by the diuine \& mightie power of God our creator./

The loue of Christ hasteneth him to come vnto the day of resurrection, \& he hath promised vs that he will come quickly, \& will not tarry./

Add. How should not he so, before they rise againe/.

Omitting $y^{\mathrm{e}}$ rest/

This my Corpes was a man $\mathrm{w}^{\text {th }}$ whome I liued al= most fifty yeares, his faithfull wyfe, in all $w^{\text {ch }}$ tyme I haue obserued an extrordinary favour of God to wards him divers wayes, wherein appeared the loue Mercy \& protection of God ouer him./

and

He hath passed thorough ${ }_{\wedge}$ amongst an army of men, very many of whom dyed of the plague, \& he escaped; he was twyce in danger to haue been drowned vpon the seaes.

In running at tilt he had a splinter of a launce

rann into

\section{[p.] 80}

\section{farre}

rann $_{\wedge}$ into the middest of his forehead; another tyme he was stricken on the head $\mathrm{w}^{\text {th }}$ a bullett, both being very dangerous escapes/

By the sicknesse of his body he was often in danger \& escaped.

\section{one}

Yf he should haue dyed in any, of these hazards; my selfe \& myne had been vtterly vndone touching my and my Childe much prejudiced worldly estate ${ }_{\wedge}$; wherin God preserued him to be a blessed helper vnto me.I

He suffered some preiudice by Gods permission touching the disposing of his inheritance, wherin 
by order of Law he prevayled against his aduersaries, $\mathrm{w}^{\text {ch }}$ recouery was effected by Gods owne hand in his great loue $\&$ mercy/, neither did euer any great sute or matter of gra importance goe against him./

vpon trim, No man was etrer abte to execute his matiec ${ }_{A}$ etrery thing beyondexpectation or deserte fell out aceor= ding to his owne desyre, \& hiseauses were etrer itust both before God \& man.I

He neuer carryed malice in his hart towards any: he was charitable \& of a compassionate mynd; he would soone forgett a wrong, \& seeke to be reconciled I haue known had for ${ }_{\wedge}$ when he hath spoken bitter words in his anger to the great offence of them to whome he spake, at the same instant he hath called for them, and intreated them to take it in the best part, and

beare $w^{\text {th }}$

\section{[p.] 81}

beare $w^{\text {th }}$ him, \& that euery rashe word $w^{\text {ch }}$ he spake in his anger was not from his harte, nor of euill meaninge ${ }^{43}$

He was not couetous nor worldly, he loued hospitalitie $\&$ bounty, he was of a free hart $\&$ good nature, he was not trecherous but faithfull in all things, nor he neuer deceiued any trust:/

He was very well instructed from his tender youth in the grounds of his fayth in Jesus Christ, \& in his truthe, $\&$ he was more sincere in his owne harte before God then he made shewe of to the world./

Neither did he justifye himselfe: for he would often confesse his owne errours \& defects, $w^{\text {ch }}$ he found in himselfe betwixte him \& God, \& desyred earnestly often tymes that the thoughts of his harte might be tur= ned awaye from them, $\&$ that he might neuer apprehend them more, $\mathrm{w}^{\mathrm{ch}}$ was an assured token 
of his election, \& that he was a blessed man, vnto whom the Lorde imputed not his sinne.

I carryed alwayes that reuerent respect towards him, in regard of my good conceipt, $\mathrm{w}^{\text {ch }} \mathrm{I}$ euer had of the good partes $\mathbf{w}^{\text {ch }} I$ knew to be in him, that I could not fynde in my harte to challenge him for the worst worde or deed $\mathrm{w}^{\text {ch }}$ euer he offred me in all his lyfe; as to say, why spake you this? or why did you that? but in silence passed over all such matters betwixt vs: so that we are parted in all loue, \& christian charitie, vntill our happy meeting in heauen./

So long as

\section{[p.] 82}

\section{this}

So long as, my corpes is aboue the earth, I can not but thinck vpon him in this manner, and beseech the Lord to enable me to performe the

$$
\text { tyme re in }
$$

trust, $w^{\text {ch }}$ in his lyfe he imposed tpon me, to the honour of God, \& the comfort of my neigh= bour,

$$
\text { good }
$$

And so rest at the Lords , pleasure to follow him in my happy end, \& blessed departure out of changable

this momentany worlde to eternall blisse in the euerlasting kingdome of heauen./

And so I take my leaue of my corpes for euer to his earthly habitation

committing him into the hands of his buryers, and $y^{e}$ performers of his honorable buryatt Funerall./

Wherein is solemnized the originalt coniunction originall

of our first ${ }_{A}$ beginning, from earth, to earth; yet not to rest there, but as a free passage vnto the free= dome of eternitie.

And

For as at the instant of our birth we are assured of nothing more then of death, so at our death 
we are of nothing more assured then that we shall liue agayne after death./

God will ever uphold it in her being, For the soule cannot be extinguished, bycause \& besides in $y^{t}$ good, the lyfe thereof is layed vp in Christ. of his divine nature, and his humane And as Christ consisteth both of soule and body,

God \& man

\section{[p.] 83}

God \& man, so we being vnited vnto him as members of his flestre blessed body, cannot but be preserued both in soule \& body thorough him who liueth for euer.l

And now my soule returne vnto thy rest, for $y^{e}$ Lorde hath beene euer good vnto thee, he hath ever preserued myne integritie $\&$ faithfullnesse vnto this man in all my lyfe I lived $\mathrm{w}^{\text {th }}$ him; \& let the same Lorde preserue \& blesse me to be a faithfull mother vnto his children, $\&$ a faithfull member of $y^{e}$ church of God, as a blessed instrument therein, euen vnto my most happie end./

And Being aged I haue but a small tyme to liue after my deare husband deceassed, who gaue mee all that he had both Lands \& goods during my lyfe, according to his last will, to be disposed by me, wholly put in trust as his executrixe.

landes Which hetherto I doe peaceably enioye, $w^{\text {th }}$ out any resistance whatsoeuer, wherein I doe admire the goodnesse of God vnto me, who hath euer taken my parte, \& righted my wrongs, as appeareth in my discourse of the peregrination of my whole lyfe to this daye $w^{\text {ch }} I$ haue set downe in this my booke of meditations./

Oh, what shall I giue vnto the Lorde for all the benefitts that he hath done vnto me?

even

I will, receiue the cup of saluation: \& call vpon 
the name of the Lorde.

$$
\text { And humbly }
$$

\section{[p.] 84}

And humbly besech the Lorde to blesse my off-spring with the graces of his holy spirit from generation to generation even vnto the very daye of the generall stel: so much resurrection, yf it be his thety , not to enioye this transitory worlde, nor the glory \& vanities thereof, as much rather Butmetratter, that they may be endued with patience \& grace, to humble themselues vnder $y^{e}$ mighty hand of God that he maye exalt them in due tyme.l

to be thankfull to him for all things, \& And to wayte his good pleasure in all things, $\&_{A}$ neuer to forgett his benefitts, $\&$ to declare the same vnto theyr children for euer.

Yf I could liue tenn thowsand generations, I were not able to expresse the least parte of the admirable blessings \& benefitts which God hath shewed vnto me \& my sayde husband in our whole lyfe vnto this daye, I

And assuredly yf I could possesse the blessings Lands $\&$ goods of all men in myne owne tyme \& being I do esteeme them as nothing in comparyson of the gifte of godds grace, to remember his benefitts with perpetuall thankes giuing for the same, $\mathrm{w}^{\text {ch }}$ ought to be performed by my selfe $\&$ my posterytie vnto the end of the world from one generation to another./

For all earthly things of this worlde, as honours

\& whatsoeuer

\section{[p.] 85}

$\&$ whatsoeuer, passeth awaye as nothing \& vanisheth lyke a shadow, in the very vsing; neither can they give any assurance thereof vnto theyr successors./ But, perpetuall thankes to God for his benefittes receiued is registred $w^{\text {th }}$ God as a thing $w^{\text {ch }}$ euer putteth him 
in mynde to continue his blessings \& to multiplye \& renue them from tyme to tyme $\mathrm{w}^{\text {th }}$ out end

Without which thankefullness to God, all good blessings \& benefittes departe awaye, as yf they had neuer been receiued.

As the places of holy seriptures are gathered \& sett vpon etrer poynt of my meditations, so tet the Lorde ingrave the same in our hartes

\section{University of New Brunswick}

\section{Notes}

1. “An Elizabethan Gentlewoman," Quarterly Review, 215 (1911), 119-138. Weigall calls the whole volume Lady Mildmay's "journal", but this is misleading since the second part of the volume - the "Meditations" - is not keyed to chronological events in the writer's life.

2. Betty Travitsky, The Paradise of Women (Westport, Conn: Greenwood Press, 1981).

3. Northampton Central Library. Weigall did not identify the location of the MS. Its pages measure 19.4 X $14.2 \mathrm{~cm}$, and on the inside cover there is a binder's ticket: "Bretherton ligavit, 1848". I should like to thank Miss M.E. Arnold and the staff of the Northampton Library for their kindness and help during my visit.

4. Paginated 1-912 with interleavings, revised sentences, and passages pasted in, but missing pp. 275-92, and incomplete at the end. The original order of composition of the "Book of Meditations" does not appear to be the sequence of the MS as it is now bound.

5. P. 4. These are among the most popular religious works of the age. Wolfgang Musculus, Common places of christian religion, trans. J. Man (London, 1566), Comontarye or exposition ... vppon the li. psalme (London, 1566); John Foxe, Actes and Monuments (London, 1563 and many reprintings); De Imitatione Christi, various translations by W. Atkinson (1504), R. Whitford (1531), E. Hake (1567), and T. Rogers (1581), all reprinted. Lady Mildmay mentions later in her Book of Meditations (p. 30) that these were the only works, besides the bible, her own mother allowed her to read. Herbert St John Mildmay notes the existence, however, of a private copy (owned by W.V.R. Fane of Fulbeck, Lincoln) of Théodore de Bèze's A briefe and piththie [sic] summe of the christian faith (first printed 1563 , with six further editions up to 1589) which bears the initials G.M. on the cover and signed verses at the end:

Seeke not to crave

that you would have

Then shall you finde

untoe your minde

That you like best

To give you rest

Grace Mildemay 
St John Mildmay also mentions portraits of Grace, Anthony, and their daughter Mary in the possession of the same owner. The portrait of Grace bears the inscription:

The minde continualli imployed

in good thinges avoideth evill,

pleaseth God, and promiseth

an happie end.

An. Dom: 1613. aetatis suae 62.

Herbert A. St John Mildmay, A Brief Memoir of the Mildmay Family (London and New York: printed privately by the Bodley Head, 1913), 75-6.

6. An exception is "agaynst all papists", four pages interleaved between pp. 482-3. Lady Mildmay makes conventional protestant attacks on Catholics, but praises many of the Jesuits as "men of great Learning, \& very expert in the scriptures." She argues that they should be given the benefit of the doubt for not knowing all the errors of the papacy, and prays for their conversion.

7. The Meditations of Lady Elizabeth Delaval written between 1662 and 1671, ed. Douglas G. Greene, Surtees Society vol. 190 (Gateshead, Surtees Society, 1978), and Margaret J.M. Ezell, "Elizabeth Delaval's Spiritual Heroine: Thoughts on Redefining Manuscript Texts by Early Women Writers," English Manuscript Studies 1100-1700, ed. Peter Beal and Jeremy Griffiths (London and Toronto, University of Toronto Press, 1992), pp. 216-37.

8. “. ... when I beganne sometimes to sett downe any parte [of my writings], I found my selfe empty, \& voyde at that very instant of any one thought or disposition to praye or meditate, or to apprehend heauenly things. Yet notwithstanding before I went from that place, the Lorde did minister such plenty of diuine matter vnto my mynde, as I was not able to comprehend \& express; so that I was constrayned to leaue off for that tyme, being afrayde to proceede or presume too farre" (p. 4).

9. This sequence is apparently superseded with another series marking longer divisions beginning "Cap. 2." at p. 32; neither series, however, runs more than halfway through this part of the MS.

10. Henry Roberts, Fames Trumpet Soundinge (London, 1589), "The honorable life and death of the most famous and noble Counseller Sir Walter Mildmay knight [in verse]."

11. Cf. The Diary of Lady Margaret Hoby 1599-1605, ed. Dorothy M. Meads (London: Routledge, 1930), and The Diaries of Lady Anne Clifford, ed. D.J.H. Clifford (Stroud: Alan Sutton, 1992).

12. St John Mildmay, 75; Roberts, A4 $4^{\text {r.v }}$.

13. Stanford E. Lehmberg, Sir Walter Mildmay and Tudor Government (Austin: University of Texas Press, 1964), 305-7.

14. Lehmberg, 307.

15. Weigall (119) supplies this name, but does not identify a source.

16. Gender and Authorship in the Sidney Circle (Madison: University of Wisconsin Press, 
1990), 200-1.

17. I am very grateful to A.S.G. Edwards for reading this article and suggesting valuable improvements.

18. John Foxe, Actes and Monuments (London, 1563).

19. This suggests knowledge of commonplace books of sententiae rather than of original works by classical writers. There is no evidence that Lady Mildmay knew Latin or Greek.

20. Psalm 1: 1-2, which Lady Mildmay paraphrases.

21. A Mrs. Hamblyn, according to Weigall.

22. William Turner, A New Herball (London, 1551, enlarged in 1562 and 1568).

23. Joannes de Vigo, The most excellent workes of chirurgerye, trans. Bartholomew Traheron (London, 1543), and/or This lytell practyce of Johanes de Vigo in medycyne (London, 1550).

24. The remainder of this paragraph is crossed out.

25. i.e. stanza.

26. Sir Walter served as M.P. first for Lostwithiel in 1545, and later for Northamptonshire from 1557 until his death $(D N B)$.

27. Perhaps a glance at Sir Walter's fellow councillor and friend Lord Burghley, or at others in Elizabeth's government, who made vast fortunes from their public offices. Sir Walter's gains, by contrast, were modest (cf. Lehmberg, 257, 307).

28. Exhibition = university scholarship for undergraduates. Besides founding and endowing Emmanuel College, Sir Walter made a generous benefaction in 1568 to his old Cambridge college, Christ's, of books, and a $£ 20$ annuity for a lecturer in Greek, a preacher, and six undergraduates (The Statutes of Sir Walter Mildmay Kt, trans. Frank Stubbings [Cambridge: Cambridge University Press, 1983]). He also left £20 to Christ's in his will (Lehmberg, 306).

29. M. P. Tilley, A Dictionary of the Proverbs in England in the Sixteenth and Seventeenth Centuries (Ann Arbor: University of Michigan Press, 1930), H88.

30. 2 Samuel 6:12-15.

31. Anthony Mildmay first drew himself to Elizabeth's attention in 1564 "at Peter House [Cambridge, where] she much commended the son of Sir Walter Mildmay; which, being a child, made a very neat and trimm Oration, and pronounced it very aptly and distinctly" (John Nichols, The Progresses ... of Queen Elizabeth [London: John Nichols, 1823], i, 173).

32. Besides the bulk of his father's property, Anthony received $£ 200$ in money, $£ 400$ in plate; his brother Humphrey received the same amount of money but $£ 300$ in plate (Lehmberg, 304-5).

33. i.e. land that was legally inalienable.

34. See below, note 38 .

35. Presumably referring to Sir Walter's granddaughter Mary. The meaning here hinges on the 
word "sufficient," for she in fact received "£667, a gold chain, and a diamond ring worth $£ 30$ " (Lehmberg, 305); but most of this may have gone towards paying off her father's debts.

36. See n. 22 above.

37. Plummett $=$ lead pen or pencil (OED, first citation 1634).

38. "Thirds" refers to the portion of a deceased husband's personal property, and the third of his landed income, which might be claimed by his widow for use during her lifetime. Thirds were often contested.

39. i. e. without any intention of remarrying, which would otherwise have been a normal expectation.

40. Altered from "indented."

41. i. e. on behalf of Grace.

42. John Talbot, fourth son of John, second Earl of Shrewsbury (Annals and Antiquities of Lacock Abbey, ed. W. L. Bowles and J. G. Nichols [London, 1835], 297-8). According to Sir Walter, he "alleadged that Sir Henrie Sharington by will made the daie before he died had graunted in revertion after his wiffe, the most parte of all his landes to the said John Talbot and his wiffe, and to hir heires, for one thousand yeares, without any rent; by that meanes leaving nothing to my sonnes wiffe but one mannour, and that not altogeather without controversie" (quoted in Lehmberg, 78).

43. This paragraph has been crossed out. 